\title{
AOR
}

Selected Papers of \#AolR2021:

The 22nd Annual Conference of the

Association of Internet Researchers

Virtual Event / 13-16 Oct 2021

\section{SOVEREIGNTY IN THE CYBERSPACE: CONTESTATION OF CONCEPTS AND POLICIES}

\author{
Yik Chan Chin \\ Beijing Normal University \\ $\mathrm{Ke} \mathrm{Li}$ \\ Jiaotong-Liverpool University
}

\begin{abstract}
The term cyberspace was first coined in science fiction (MacKellar, 2019: 13). Since the 1980s, many scholars and organizations have tried to define the concept of cyberspace. For example, International Telecommunication Union (ITU) defines cyberspace as "the physical or non-physical domain consisting of all or some of the elements including computers, computer systems, networks and their software support, computer data, content data, traffic data and users" (International Telecommunication Union, 2016: 6). Some theorists assert that cyberspace transcends geographical and national boundaries and puts pressure on traditional notions of sovereignty and security (Fang, 2018: 14).
\end{abstract}

In international relations and law, the traditional concept of sovereignty consists of four principles: 1) every state has the right to monopolies the exercise of certain powers from the perspective of its territory and its citizens (monopoly of power); 2 ) all states are equalized; 3) an official of a state who lives in another state enjoys reciprocal immunity for various purposes; and 4) sovereignty implies opposition to any extraterritorial (or international) power interfering or intervening in the affairs of the territory. The scope of this traditional concept of sovereignty is limited by the UN Charter, which presupposes the prohibition of the use of force as a premise for the concept of sovereignty and excludes some substantive areas from the set-aside (e.g., human rights). (Weber, 2010: 12). In the context of global interdependence, it is difficult to maintain an absolute concept of sovereignty (Bhandar, 2011). With the advent of global telecommunications infrastructure and the Internet, the scope of sovereign authority is however limited (Couture and Toupin, 2019: 2308). It is the contradictory nature of the traditional concept of sovereignty makes sovereignty in cyberspace one of the most controversial issues in Internet governance today.

Suggested Citation (APA): Chin, Y.C., Li, K. (2021, October). Sovereignty in the Cyberspace: Contestation of Concepts and Policies. Paper presented at AoIR 2021: The 22nd Annual Conference of the Association of Internet Researchers. Virtual Event: AolR. Retrieved from http://spir.aoir.org. 
As one of the first concepts to emerge, the concept of 'cyber sovereignty' often appears alongside the notion of 'national sovereignty'. The similarities and differences between these two concepts have always been the focus of academic debate. The concept of cyber sovereignty evolves as a manifestation of data security and geopolitical issues arising from the digital economy and technological competition. For fear of jeopardizing sovereignty, many states refuse multilateral modes of cooperation, leading to a fragmented system of global governance (Stevens, 2017). However, individual national strategies do not effectively address the problems of cyberspace on a global scale, such as fake news and cybercrime. Despite the partial transfer of national sovereignty to the global level after World War II, such as the WTO, there are currently few multilateral binding legal instruments and regulations in cyberspace, and collective sovereignty has not yet been achieved on a global scale. The large differences between developed and non-developed cyber countries on the issue of sovereignty in cyberspace also make it difficult to build a global framework for Internet governance.

However, in recent years, the term 'sovereignty' has also been frequently associated with the terms 'digital', 'data' and 'technology'. Various claims of cyberspace sovereignty, including 'data sovereignty', 'digital sovereignty' and 'technological sovereignty', have attracted widespread attention. Within this context, in this research, we examine the various academic positions and governments policies on different "sovereignty" concepts in cyberspace, and to explore the controversies, evolution and future development of these concepts.

The paper considers sovereignty in cyberspace as the subject of the study, and conducts a systematic interdisciplinary (communication, political and legal) study of its conceptualizations and state policies. The research aims to answer the following research questions: 1 ) what are the definitions of the academic community on these concepts including cyber, 'digital', 'data' and 'technology sovereignty; 2) what are the positions and claims of major governments on these sovereignties; and 3) what are the overlaps, differences and conflicts between those positions and the underlying reasons? The purpose of this paper is to explore the process of development of the "sovereignty" norms and policies in cyberspace, with particular attention to the positions and claims of academics and governments.

Methodologically, this paper will use a historical documentary analysis approach. The types of documents used include two categories: (1) Primary sources: Initiatives, laws, regulations, drafts, ordinances and strategic proposals issued by governments on sovereignty in cyberspace; 2 ) secondary source: academic literatures related to various concepts of sovereignty in cyberspace, including journal papers, academic conference reports and books. In this paper, government documents from China, the EU and the US for the period 2010-2021 will be chosen as the main subjects of study. There have been a major conceptual and position differences among these countries/regions on the "sovereignty " in cyberspace, they represent the focus of the debates.

Suggested Citation (APA): Chin, Y.C., Li, K. (2021, October). Sovereignty in the Cyberspace: Contestation of Concepts and Policies. Paper presented at AoIR 2021: The 22nd Annual Conference of the Association of Internet Researchers. Virtual Event: AolR. Retrieved from http://spir.aoir.org. 
This study shows that the US, the EU and China have different claims and positions on cyberspace. The US has a firm grip on the discourse of cyber sovereignty by advocating an 'America First' and 'multi-stakeholder' model of cyber governance. The European Union, while largely sharing the US model, has retained its ability to act by introducing the concepts of "digital sovereignty" and "technological sovereignty". China, on the other hand, has stressed on the multilateralism and legally binding cooperative sovereignty at the international level.

\section{References}

Bhandar B (2011) The conceit of sovereignty: toward post-colonial technique. In: Lessard B (ed) Stories Communities: Narratives of Contact and Arrival in Constituting Political Community. Vancouver, BC, Canada: University of British Columbia Press, pp. 66-88.

Couture S and Toupin S (2019) What does the notion of "sovereignty" mean when referring to the digital? New Media \& Society 21(10): 2305-2322.

Fang B (2018) Cyberspace Sovereignty: Reflections on Building a Community of Common Future in Cyberspace. Beijing: Science Press.

International Telecommunication Union (2016) ITU-T X-SERIES

RECOMMENDATIONS: DATA NETWORKS, OPEN SYSTEM COMMUNICATIONS AND SECURITY. Telecommunication security. Overview of cybersecurity.

Mackellar C (2019) Why Use the Term 'Cyberneuroethics'? In: Mackellar C (ed.) Cyborg Mind: What Brain-Computer and Mind-Cyberspace Interfaces Mean for Cyberneuroethics. New York and Oxford: berghahn.

Stevens T (2017) Cyberweapons: An Emerging Global Governance Architecture. Palgrave Communications 3(16102): 1-6.

Weber RH (2010) NEW SOVEREIGNTY CONCEPT IN THE AGE OF INTERNET? Journal of Internet Law 14(2): 12-20.

Ministry of Foreign Affairs of China (2020) Global Initiative on Data Security. Cyberspace Administration of China (2016) Cyberspace Security Strategies. EU (2020) The European Data Strategy. EU (2020) European Digital Sovereignty. EU (2018) General Data Protection Regulation (GDPR). 
U.S. Department of Commerce and European Commission (2016) EU-U.S. Privacy Shield Frameworks. the Association of Internet Researchers. Virtual Event: AolR. Retrieved from http://spir.aoir.org. 